\title{
Thinking about Peace in Ancient India
}

\author{
JOHANNES BRONKHORST
}

\begin{abstract}
Aśoka
Indian history begins, in a certain way, in the third century BCE with the inscriptions of Aśoka. ${ }^{1}$ These inscriptions are among the earliest surviving written testimony from the subcontinent. Their contents are surprising, to say the least. They are messages for his subjects from Emperor Aśoka, who calls himself "the beloved of the gods." And they tell us a lot about the emperor himself, especially about his religious and generally moral attitudes. We know from these inscriptions that Aśoka turned to Buddhism at some point in his life, and that he considered himself a lay Buddhist. Not unrelated, but of more immediate interest for our topic, are the regrets that Aśoka expresses about the violence he had perpetrated during the conquest of a region in eastern India, Kalinga. We find this in the so-called thirteenth Major Rock Edict, extracts of which I present here in the somewhat free rendering of Romila Thapar:
\end{abstract}

When he had been consecrated eight years the Beloved of the Gods, the king Piyadassi, conquered Kalinga. A hundred and fifty thousand people were deported, a hundred thousand were killed and many times that number perished.

Peace in the Ancient World: Concepts and Theories, First Edition. Edited by Kurt A. Raaflaub. (C) 2016 John Wiley \& Sons, Inc. Published 2016 by John Wiley \& Sons, Inc. 
On conquering Kalinga the Beloved of the Gods felt remorse, for, when an independent country is conquered the slaughter, death, and deportation of the people is extremely grievous to the Beloved of the Gods, and weighs heavily on his mind. What is even more deplorable to the Beloved of the Gods, is that those who dwell there, whether brahmans, śramanas, or those of other sects, or householders who show obedience to their superiors, obedience to mother and father, obedience to their teachers and behave well and devotedly towards their friends, acquaintances, colleagues, relatives, slaves, and servants-all suffer violence, murder, and separation from their loved ones. Even those who are fortunate to have escaped, and whose love is undiminished [by the brutalizing effect of war], suffer from the misfortunes of their friends, acquaintances, colleagues, and relatives. This participation of all men in suffering, weighs heavily on the mind of the Beloved of the Gods. ... Today if a hundredth or a thousandth part of those people who were killed or died or were deported when Kalinga was annexed were to suffer similarly, it would weigh heavily on the mind of the Beloved of the Gods. ${ }^{2}$

Aśoka tries to remedy the situation by promoting the victory of Dharma, which approximately translates "righteous rule, correct behavior." It covers, for Aśoka, a variety of virtues, including generosity, medical care for humans and animals, religious tolerance, and much else. Virtually all his Rock Edicts deal with the propagation of Dharma within and beyond his empire. The thirteenth Major Rock Edict continues:

The Beloved of the Gods considers victory by Dharma to be the foremost victory. And moreover the Beloved of the Gods has gained this victory on all his frontiers to a distance of six hundred yojanas [i.e. about 1500 miles], where reigns the Greek king named Antiochus, and beyond the realm of that Antiochus in the lands of the four kings named Ptolemy, Antigonus, Magas, and Alexander; and in the south over the Colas and Pāndyas as far as Ceylon. Likewise here in the imperial territories among the Greeks and the Kambojas, Nābhakas and Nābhapanktis, Bhojas and Pitinikas, Andhras and Pārindas, everywhere the people follow the Beloved of the Gods' instructions in Dharma. Even where the envoys of the Beloved of the Gods have not gone, people hear of his conduct according to the Dharma, his precepts and his instruction in Dharma, and they follow Dharma and will continue to follow it. ${ }^{3}$

We should not conclude from this that Aśoka had renounced all use of violence. Indeed, as Hans Bakker points out, "he is not slow to add that those subjugated by him 'should be told of the power (to punish them) which Devānāmpriya [i.e. Aśoka, JB] (possesses) in spite of (his) repentance, in order that they may be ashamed (of their crimes) and may not be killed'."4

Aśoka is no doubt a unique and perhaps also extreme case in the ancient world. His empire stands at the beginning of the political history of classical 
India. Its memory bequeathed to subsequent rulers and thinkers an ambiguous message. ${ }^{5}$ This will be clear from the following passage, which I quote from Hartmut Scharfe's book The State in Indian Tradition:

Even though Indians admired heroes and glorious conquests throughout their history, the ideal kingdom of the epic and classical texts was seen as a state of permanent peace. The notion of a single state for the whole "world," (i.e. the Indian subcontinent) could satisfy from the time of the Brāhmana-texts on the thirst for ultimate glory and, at the same time, put an end to the perpetual wars between a multitude of competing dynasties. No Hindu ruler ever achieved that goal, and the attempts to reach it led to numerous and bloody conflicts. Each king is potentially and ideally a vijigīṣu "desirous to conquer [the world]" and aspires to be a sār va -bhauma "[king] ruling the whole world" or a cakravartin. ${ }^{6}$

The ultimate aim of permanent and universal peace led in practice to ceaseless and relentless war.

\section{Brahmanism}

It makes sense to distinguish two major currents in the post-Mauryan intellectual history of India: the Brahmins and the Buddhists. The thinkers of these two currents dealt quite differently with the inherited ideal of permanent and universal peace.

The Brahmanical thinkers, to begin with, were pragmatic in their approach. This is clear from the Brahmanical texts that deal, as a whole or in part, with statecraft. The one called Arthaśāstra ("Treatise on Statecraft") is no doubt the oldest surviving Brahmanical text that exclusively deals with such issues. Let me say a few words about it.

Brahmanical tradition ascribes the authorship of the Arthasasastra to a person variously called Cānakya and Kauțalya/Kautilya. Still according to Brahmanical tradition, this person was a Brahmin who advised King Candragupta, Aśoka's grandfather and the founder of the Mauryan empire, which Aśoka inherited and expanded. This Brahmin, moreover, was such a cunning politician that without him Candragupta would not have succeeded in creating his empire. ${ }^{7}$

The identification of the two persons - the minister of Candragupta and the author of the Arthaśāstra-is no doubt apocryphal. ${ }^{8}$ The fact that no writing was used in India at the time of Candragupta Maurya is one reason to think so. ${ }^{9}$ Another is the fact that the Arthasāastra presupposes a kingdom that can be surrounded by more powerful rivals, whereas the empire of Candragupta and 
his successors could not be encircled. ${ }^{10}$ Then there is the obvious advantage which more recent Brahmins could derive from the claim that the Mauryan empire-which had not been sympathetic to them - had really been created by a Brahmin, using the methods which those more recent Brahmins promoted among the rulers that were their contemporaries. ${ }^{11}$

The Arthaśāstra (13.4.55-63) distinguishes four possible ways of conquering the world. ${ }^{12}$ It does not waste words on this final goal. Most of the text deals with concerns - such as ruling a state and taking maximum advantage from the relative strengths and weaknesses of neighboring kings-that come up when conquering the world is still a distant dream. It does so matter-of-factly, with few theoretical digressions or justifications. One may assume that the final goal of permanent and universal peace is to be considered a hidden justification for the sometimes doubtful recommendations that the text contains, but if so, the text does not say so. One has the feeling that the Brahmins who composed the Arthaśāstra were less interested in dreams than in securing and safeguarding their own position at and around the royal courts.

This does not mean that the Arthaśāstra is not interested in ordinary peace, the kind of peace that may reign between neighboring kingdoms or within a kingdom. However, this kind of peace is not always an aim in itself. Frequently, it is, as so many other things in this text, a means to an end; that is, to the intermediate end of maintaining power and, of course, of maintaining the social order in which Brahmins occupy a privileged position. The idea, for example, that kings should look after the well-being of their subjects is not unknown to the text. Typically, it does not present this as a duty of the king, but as a topic that secret agents in disguise should discuss in public places in order to restrain the common people and to find out who among them might feel critical of the present king (1.13.1-14). ${ }^{13}$ And peace with a neighboring king is but a temporary ploy, to be abandoned once one has the means to overthrow or conquer him. Peace is also useful for creating confidence in one's neighbor, whose power can then be undermined by secret manipulations and occult means (7.1).14

Another classical Brahmanical text-the so-called Laws of Manu (Manusmrti or Māna va Dharmaśāstra)—dedicates some of its chapters to matters of state. Like the Arthaśāstra, it unabashedly describes the task of kings as acquiring with military force what they have not yet acquired, to preserve with vigilance what they have acquired, to augment what they have preserved through profitable investments, and to distribute through gifts what has been augmented in this manner (7.101). The recipients of the gifts, to be sure, are the Brahmins. The Laws of Manu is not in favor of war, but the reason is not the promotion 
of peace as such, but rather the consideration that war brings risks that may be avoided by trying out other means first (7.198-200):

He [the king] should strive to triumph over his enemies through conciliation, gifts, and fomenting dissension, employed collectively or separately, but never through war. Victory and defeat in battle are uncertain for the two combatants; he should, therefore, avoid war. When the aforementioned three strategies fail, then let him, always on guard, pursue war in such a manner that he will triumph over his enemies. ${ }^{15}$

War remains an honorable occupation, as the following verse shows (7.89):

When kings fight each other in battles with all their strength, seeking to kill each other and refusing to turn back, they go to heaven.

The Pañcatantra, to give one more example, though presenting its political advice in charming fables, is no more peace-minded than the two preceding works. The title of its first book- "On causing dissension among allies" in Olivelle's translation-reveals its cynical attitude, while book III- "On war and peace"-explains with the help of stories how wit can be used to attain one's goals without resorting to war. ${ }^{16}$ No idealism here, only calculation.

The Brahmanical political tradition, then, was not actively in search of peace. Quite on the contrary, it impressed upon rulers that the expansion of their realms was part of their duty and that war in the service of that aim was justified, even obligatory. This is not just the attitude of books that are, wholly or in part, political manuals, such as the Arthasasastra, the Laws of Manu and the Pañcatantra just considered. It also finds expression in such texts as the Bhaga vadgitā, arguably the most popular book of Hinduism until today. The Bhaga vadgita contains the teaching imparted by God to the warrior Arjuna, just before a battle in which Arjuna is going to destroy many friends and family members. Arjuna's scruples are presented in detail, but they are discarded with the argument that it is a warrior's duty to fight. Political peace in the sense of avoidance of war is not part of the ideology of this text, as it is not part of most other texts belonging to the Brahmanical tradition. ${ }^{17}$

Brahmanical political thought succeeded in exerting ever-greater influence on the rulers of the numerous kingdoms that the South Asian subcontinent has known. Countless panegyrics that survive in inscriptions-especially from the time of the Guptas onward, that is, from about the fourth century $\mathrm{CE}-$ praise rulers for the conquests they have made, and for the harm they have been able to inflict upon their neighbors and competitors. ${ }^{18}$ These inscriptions are depressing reading and could not be more different in their general tone from 
the inscriptions of Aśoka with which we began. The victory of Brahmanism in the realm of religious, social, and political ideas expressed itself in what might be called a celebration of war, both in reality and in rhetorical contexts.

Still, we should not conclude from what precedes that Brahmins did not want to live in peace. Other things being equal, we must assume that everyone, with the possible exception of born and committed warriors, wishes to live in peace. But Brahmins wanted peace in conditions that were favorable to them. This meant in practice that often they encouraged warfare-not least because, in the general political situation of their day, kings who were ready to engage in war were more likely to stay in power than those who were not. Brahmanism's success was in part due to the fact that it did not hesitate to promote war. By doing so, it betted on the right horse, so to say. Conversely, this political ideology suited ambitious kings, and the kings who adopted this ideology may, on the whole, have had less inner resistance to war and therefore greater chances of staying in charge or even extending their power.

The pragmatic attitude of the Brahmanical texts with regard to the realities of war and peace has much to do with the fact that Brahmanism, as it managed to impose itself during the centuries following the collapse of the Mauryan empire, was primarily a vision of society. Brahmanism was no religion that attempted to make religious converts. Indeed, if we look upon the ideas found in the Vedic corpus of texts as being the religious doctrines of Brahmanism, we must conclude that Brahmanism kept its doctrines secret: large portions of the population had no right whatsoever to hear (or read) the Veda. The Brahmins themselves were barely interested in those doctrines. Brahmanism, I repeat, was primarily a vision of a highly stratified society, in which Brahmins occupied the highest position and kings were there to create and expand kingdoms. Brahmanism succeeded over time in imposing itself on large parts of the South Asian subcontinent and beyond. Not least among the reasons of its success was its capability to help rulers by giving them the pragmatic advice they needed.

What about the ahimssā ("nonviolence") for which India has become so famous? The answer is given in the following passage, which I borrow from an article by Jos Gommans:

The ultimate aim for both Brahmins and kings was not earthly power but eternal salvation; the way thither was not conquering the world but renouncing it. His pursuit also involved the well-known Indian ideal of ahimsāa or non-injury to life. As it was only the ascetic who could really live up to it, world-renouncement and ahimsā had to be internalized by those whose dharmic role could not escape the evil consequences of worldly action. As such, this second-best option was most fitting for kings and warriors wielding earthly power. Hence, their himsā (violence, JB) had to be detached, without self-interest; ahimsā only serving to calm their inner world. This 
also explains why even martial sects of ascetic warriors saw no problem at all in subscribing to the vow of ahimsā ... In any case, it is clear that ahimsā was not meant to establish peace in the public realm as had been the prime objective of the European peace movements. ${ }^{19}$

\section{Buddhism}

Buddhist thinkers were not quite as pragmatic as their Brahmanical confrères. This is hardly surprising. Buddhism did not start out as a vision of society, even less as a model to be followed in ruling a state. It taught a path to escape from rebirth, and following this path implied leaving society and surviving henceforth by begging. The nature of the society left behind was of little concern to the early followers of the Buddha. ${ }^{20}$

This initial situation did not last long. Buddhism soon became the victim of its own success. The community of monks and nuns organized itself, and monasteries were created. Questions regarding the interaction between the Buddhist community and society at large became inevitable, all the more so since the core members of the Buddhist community, the monks and nuns, had few or no worldly possessions. In order to build monasteries and places of worship, a steady stream of gifts from donors was required. The Buddhists could not forever go on hiding their heads in the sand as far as questions of society and its political organization were concerned. But the challenge they were confronted with was too great to deal with.

Consider first an early text, part of the Buddhist canon, that deals with the organization of society and explains how it came to be as it is. This text, the Agga ñña Sutta, criticizes the Brahmanical vision of society and rejects the notion according to which Brahmins are fundamentally different from all other members of society. Brahmins had justified their claim to superiority with the help of a myth, which recounts that Brahmins, unlike all other human beings, were born from the mouth of the Creator God. The Aggañña Sutta does not accept this and presents a creation story of its own. In this alternative story, differences between people only came about as a result of different behavior in some unspecified past. Brahmins, for example, are the descendants of people who meditated or compiled books; the text hastens to add that Brahmins have a common ancestry with all other classes of society. The kingly class came about when people chose one from among themselves to impose order on society. Once again the text emphasizes the common origin of the king with the other classes. ${ }^{21}$

The Aggañ̃na Sutta, while reacting to Brahmanical ideas, adopts some of them. It criticizes the fundamental difference between the four classes of 
society taught by the Brahmins, yet accepts this division of society as real. It also accepts without discussion that kings behave the way kings do. In the words of the Aggañna Sutta, a king is a being who, appointed by the rest of the population, "would show anger where anger was due, censure those who deserved it, and banish those who deserved banishment."22

Yet this is where the shoe pinches. Buddhism teaches a path that leads to liberation. This path is open to all human beings, not just Brahmins or some other group. Buddhism is therefore bound to encourage behavior that, in the long or short run, leads to that goal. The strong-arm tactics that worldly rulers use (and may be compelled to use) do not lead in that direction. In fact, they do the opposite. The Brahmins could maintain that a certain class of people, the warriors, were born with the obligation to use violence in appropriate circumstances. They could point out that a warrior who did not use violence in such circumstances might expect to be punished for this omission, in this or in a next life. For Buddhists this was harder to maintain. They recognized no separate class of warriors, fundamentally different from other human beings, with different obligations and different fates. For Buddhists there was no fundamental difference between a monk and a warrior. If violence was wrong for the one, it was wrong for the other.

This is the conundrum in which Buddhist theoreticians of political power found themselves. Was there a right way of ruling a country, without violence? In answering this question, the memory of the Mauryan empire, and especially of its emperor Aśoka, appears to have made itself felt. Aśoka, as we have seen, talked about the victory of Dharma, that is, of "righteous rule, correct behavior." The notion of Dharma in connection with political power had great appeal to the Buddhists. They thought and spoke about a Dharma-king, who conquered the world in an unobjectionable manner. The Cakka vatti-Sîhanāda Sutta, another canonical text, describes what happened to one such righteous king to whom one day a Wheel appeared: ${ }^{23}$

Then, rising from his seat, covering one shoulder with his robe, the king took a gold vessel in his left hand, sprinkled the Wheel with his right hand, and said: "May the noble Wheel-Treasure turn, may the noble Wheel-Treasure conquer!" The Wheel turned to the east, and the king followed it with his fourfold army. And in whatever country the Wheel stopped, the king took up residence with his fourfold army. And those who opposed him in the eastern region came and said: "Come, Your Majesty, welcome! We are yours, Your Majesty. Rule us, Your Majesty." And the king said: "Do not take life. Do not take what is not given. Do not commit sexual misconduct. Do not tell lies. Do not drink strong drink. Be moderate in eating." And those who had opposed him in the eastern region became his subjects. 
Then the Wheel turned south, west, and north... (as before). Then the WheelTreasure, having conquered the lands from sea to sea, returned to the royal capital and stopped before the king's palace. ${ }^{24}$

We do not know how many Buddhist monarchs waited in vain for a WheelTreasure to appear and help them in the task of conquering the world. Without a Wheel-Treasure the task became much harder, and would inevitably breach the rules that the king was supposed to promulgate, especially the ones about not taking life and not taking what is not given. In spite of these drawbacks, there were always volunteers to carry out the job, even without Wheel-Treasure. The question is, what advice could their Buddhist counselors give them?

The answer is, very little. We possess some works whose stated aim is to give advice to (sometimes identifiable) kings. One of these is a letter sent to the young King Kaniṣka by the Buddhist scholar Mātrceta in the second century CE. It is not clear to which Kanișka the letter was addressed (several kings bore that name), nor indeed whether it was really sent to a king of that name. ${ }^{25}$ However, the most famous Kaniṣka (Kaniṣka I) was a king of the Kuṣanna dynasty, about whom the Indian historian Romila Thapar writes: "The Kushana dynasty was in the ascendant in central Asia under Kanishka, whose relationship to the earlier kings has been confirmed by the recent discovery of an inscription in Afghanistan. In this he claims that he conquered hindo/India, i.e. the better-known north-west of India, and proclaimed his conquest in all the cities as far as Champa (in the middle Ganges Plain)." ${ }^{26}$ Perhaps the most striking feature of Mātrceta's letter, addressed as it is to the successor, descendant, and namesake of a king known for his conquests (if not to that king himself), is its emphasis on saving the life of animals. Nothing at all is said about the killing of humans. ${ }^{27}$

Nāgārjuna was more or less a contemporary of Mātrceța. ${ }^{28}$ His Precious Garland contains advice for kings. Some of the passages involved show that Nāgarijuna's political ideas were still very close to those that we found in the canonical texts studied above. Consider the following verse: "Through proper honoring of stūpas, honorable beings, Superiors, and the elderly, you will become a Universal Monarch, your glorious hands and feet marked with [a design of] wheels." ${ }^{29}$ A Universal Monarch is the same as the Dharma-king whom we met earlier. Like the Dharma-king, the Universal Monarch is associated with wheels, with the difference that this time wheels appear as marks in his hands. Universal kingdom, here as well as there, is presented as the outcome of virtue. Violent conquest, the verse suggests, can be avoided. 
Other passages from the Precious Garland are no more practical, even though the pious and virtuous intentions of its author cannot be doubted. No one would be averse to living in a country ruled by Nāgārjuna's ideal king. Whether such a king would remain in charge for long is a different question. It seems that even Nāgārjuna himself had some doubts, for he ends his political advice with the following verse: "However, if from the unrighteousness of the world it is difficult to rule religiously, then it is right for you to become a monastic for the sake of practice and grandeur." ${ }^{30}$ In other words, trying to be a good and virtuous king may turn out to be impossible. In that case the Buddhists have no further advice to offer, except that it is time to turn one's back to the world and become a monk.

The Letter to King Gautamīputra, attributed to the same Nāgārjuna, is even less practical in its advice than the Precious Garland, and even more insistent that a king really finds himself in the wrong place: "[In choosing] between the one who conquers [attachment to] the ever unsteady and momentary objects of the six sense-organs and the one who conquers the enemy's army in battle, the wise know the first to be a far greater hero." ${ }^{31}$ The advice it gives is, as the text itself admits, more suitable to monks than to kings: "It is difficult even for a monk in isolation to follow the counsel which has been given to you; [yet] make this life meaningful through cultivating the quality of the essence of any of these practices." 32

It is conceivable, though not certain, that Mātrceța and Nāgārjuna had read Aśvaghoșa's Life of the Buddha (Buddhacarita).${ }^{33}$ Aśvaghoșa puts the following assessment of kingship in the mouth of the future Buddha after he has left home but before he has reached enlightenment:

In what way could it be right for a wise man to take sovereignty on himself? It is the abode of delusion in which are to be found fearfulness, the intoxication of pride, weariness and loss of Dharma by the mishandling of others. For kingship is at the same time full of delights and the vehicle of calamity, like a golden palace all on fire, like dainty food mixed with poison, or like a lotus-pond infected with crocodiles. ... For it is better to eat herbs in the forest, embracing the highest contentment as if one were concealing a jewel, than to live with the dangers to which sovereignty is exposed, as if with loathsome black snakes. ${ }^{34}$

We may assume that Aśvaghoṣa, one of the first Buddhist authors to compose works in Sanskrit, addressed a courtly audience, as did Mātṛceța and Nāgārjuna. The topic he is dealing with in his poem allows him to be even more outspoken than the other two, and he does not mince his words.

To conclude this discussion I will cite one more Buddhist text, Vasubandhu's Abhidharmakośa Bhāṣya, which dates from the fourth or fifth century CE. This text mentions kings, judges (daṇụanetṛ), and ministers (vyāvahārika) as self-evidently 
(arthatah) belonging to the group of indisciplined people along with fishermen, hunters, bandits, executioners, jailors, and others. ${ }^{35}$ No comments are called for.

Indian Buddhism, then, did not develop much in terms of thought about political peace, not at least during the period under discussion. And yet the Buddhists, including the Buddhist thinkers who developed so much acuity in other areas of thought, had to live in the real world in which political peace was of the greatest importance to them. How do we explain their lack of imagination in this crucial realm?

The answer presents itself, I believe, if we look at some more recent developments in South Asia and project our findings back into the period under consideration. Recall, to begin with, that there was in India a joint presence of Brahmins and Buddhists for many centuries. These two competed with each other in several areas. ${ }^{36}$ The history of Indian philosophy during the first millennium $\mathrm{CE}$, for example, can be thought of as the history of a long debate between Brahmanical and Buddhist thinkers. The competition between the two was not confined to philosophy. They competed for royal favors in a variety of ways and areas. An enumeration is not necessary at this point. There were, however, some areas in which the two did not compete, which the Buddhists abandoned to the Brahmins, and which they had apparently abandoned from an early date onward. An example is the field which combines astrology, astronomy, and mathematics, but which is jointly thought of as one single field in the Indian tradition. This is a field in which a succession of authors made some important contributions. These authors were often Brahmins, sometimes Jainas, but never Buddhists. ${ }^{37}$ The explanation appears to lie in the circumstance that Buddhists refused to be associated with anything that had the remotest connection with predicting the future, including astrology. And indeed, the people who, according to an ancient legend, predicted the future of the Buddha soon after he was born, were Brahmins. The Buddhists, it appears, were ready to have their future predicted, at least in certain circumstances; they were not ready to do the predicting themselves. As a result, they cut themselves out of the market of all future developments in the area of astronomy and mathematics.

Surprising as it may seem, it appears that the Buddhists also left matters relating to statecraft to Brahmins. This is most clearly visible in certain Southeast Asian countries which, though Buddhist, kept Brahmins at the court to advise the king. Thailand does so until today. In Ceylon, the Buddhist kings voluntarily took advice about governing from Brahmanical texts, including the ones we have considered, the Arthaśāstra and the Laws of Manu. ${ }^{38}$ Here and elsewhere the Brahmins presented themselves as specialists, with sophisticated manuals at their disposal and useful advice for the practicalities of governance. The Buddhists had 
no such tradition and, as we have seen, had major difficulties creating one. In this area, it appears, the Buddhists did not enter the competition. They left this area to the Brahmins, conceding that the latter were the specialists in this domain.

This situation did not last indefinitely. The later history of Buddhism in India shows that a variety of modifications permitted this religion to enter into competition with the Brahmins after all, even in realms that directly concerned the state. The difficulty, as we have seen, was that Buddhism found it difficult to present a picture of and a justification for a society in which there was place for real kings and realistic policy. ${ }^{39}$ Worse, Buddhism did not have much place for positions people might occupy in society outside the monastery. It concentrated on encouraging people to become monks and nuns. Failing this, it encouraged them to become lay followersupāsakas or upāsikās-but the obligations it imposed upon them, and the further vows that these lay followers were expected to make, put them in a category quite distinct from the ordinary citizen and excluded them from many occupations. ${ }^{40}$ For others, most notably those involved in ruling the country, Buddhism had but little advice. Those others should somehow fit into the dominant vision of society, that of the Brahmins. As long as Buddhism had nothing of its own on offer, it could not but accept that vision, no doubt with regrets. The pressure to come up with something more satisfactory must have been great. It led to developments, which we will now briefly consider.

Let us first look at the so-called Jatakas. These are stories that tell what the most recent Buddha had gone through and done in earlier lives. These deeds had contributed to his ultimate victory, that of becoming a Buddha. However, the most recent Buddha is not the only Buddha there has been, or will be. Already in canonical times, Buddhists had come to believe that there had been Buddhas before the most recent one, and that there will be others in the future. Obviously, the highest aim these Buddhists could aspire to was that of becoming a Buddha themselves. This aim, they thought, was to be preferred to the simpler and more self-centered one of becoming an enlightened Arhat (liberated Buddhist saint). Some of these Buddhists actually made a resolve to become a Buddha. This resolve is known by the name bodhicitta. ${ }^{41}$ Those who have generated it are henceforth Bodhisattvas, future Buddhas. These new Bodhisattvas drew inspiration from the Jaatakas and tried to imitate the deeds there recounted to the extent possible. ${ }^{42}$ This in its turn had interesting consequences; for example, a serious and committed Buddhist did not have to be a monk, he might stay in society and play a role in it, just as the most recent Buddha had occupied various positions in society in earlier lives. ${ }^{43}$ 
This last point is illustrated in an early text belonging to the Mahāyāna branch of Buddhism, The Inquiry of Ugra (Ugrapariprechā). Half of this text gives advice to householder Bodhisattvas, including the following:

The householder Bodhisattva seeks wealth according to the Dharma; he does not seek it according to what is non-Dharmic. He seeks it fairly, not unfairly. He pursues right livelihood, not wrong livelihood. ... not desiring happiness for himself, he causes all beings to attain happiness. Unmoved by profit or loss, fame or infamy, praise or blame, happiness or suffering, he transcends worldly things. He does not become arrogant because of amassing profit and wealth, nor is he discouraged by the absence of profit, fame, or praise. ... With respect to his undertakings, he is firm in his sense of obligation. ${ }^{4}$

\section{Furthermore:}

The householder Bodhisattva who lives at home, by being free of attachment and aversion, should attain equanimity with respect to the eight worldly things. If he succeeds in obtaining wealth, or a wife, or children, or valuables, or produce, he should not become proud or overjoyed. And if he fails to obtain all these things, he should not be downcast or distressed. ${ }^{45}$

Note that the householder Bodhisattva depicted in this text passes his time seeking wealth. It is true that there are limits to the methods he can use in doing so, but as long as he observes these, he can participate in economic life. He can also marry and have children, that is to say, participate in ordinary social life.

Another Mahāyāna text that especially addresses lay people is the Sūtra on U pāsaka Precepts (U pāsakaśîla Sūtra). This text admonishes the lay Bodhisattva to take a number of vows, some of which concern future lives. The following are of special interest in the present context:

I vow that wherever I am reborn, I shall not take rebirth as a woman, as one without sexual organs, or with both [male and female] sexual organs, or as a slave. ... [I vow] not to be born in a bad country or borderland but to be born into a noble family with outstanding physical appearance and great wealth. ${ }^{46}$

Once again we hit upon the theme of wealth, this time inherited wealth. Clearly, there is nothing wrong with wealth according to the author of this passage. Quite on the contrary, wealth may accrue to a person because he has taken a Bodhisattva vow in an earlier existence. ${ }^{47}$ But acquired wealth also befits a lay Bodhisattva:

The Bodhisattva has to perfect eight dharmas to benefit himself and others. What are they? [They are:] (1) a long life, (2) superior appearance, (3) great physical strength, (4) noble birth, (5) much wealth, (6) being a male, (7) eloquence, and (8) fearlessness when facing great assemblies of people. ${ }^{48}$ 
And how does one perfect these dharmas?

The Bodhisattva mahāsattva has compassion and does not kill for immeasurable lives; for this reason he obtains a long life. In measureless lives he constantly gives away clothing and lamps, and for this reason he enjoys a superior appearance. In measureless lives he always destroys arrogance, and for this reason he is born in a noble family. In measureless lives he always gives food to others, and for this reason he obtains great physical strength. In measureless lives he always takes delight in speaking the Dharma, and for this reason he obtains great wealth. In measureless lives he loathes the female body and for this reason he is born as a man. In measureless lives he keeps precepts sincerely, and for this reason he is eloquent. In measureless lives he makes offerings to the Three Treasures, and so he is fearless in the assembly. ${ }^{49}$

Wealth, and all the other advantages that certain people have with respect to others, are here presented as a virtue, or rather as the outcome of virtue in earlier existences.

Let me emphasize the importance of the development here sketched. Buddhism had from the beginning presented itself as a path leading to the end of suffering and rebirth. This path consisted in saying farewell to the world and dedicating oneself to the spiritual practices taught by the Buddha. Monks and nuns actually did so (or were supposed to do so), upāsakas and upāsikās did so to a considerable degree. Those who did not do so and remained in the world had an ill-defined position in the Buddhist scheme of things. They might feel sympathetic toward the Buddhist teaching and community, but it was not clear whether and to what extent they could be thought of as partaking in the Buddhist path.

Non-monastic Buddhists could not forever remain in limbo. They found a place for themselves by laying stress on the importance of accumulating merit. Recall what, according to authors like Nāgāijuna, one had to do in order to become a Universal Monarch. The answer is: acquire merit. One verse spells out what kind of merit is meant: "Through proper honoring of stūpas, honorable beings, Superiors, and the elderly, you will become a Universal Monarch, your glorious hands and feet marked with [a design of] wheels." In other words, accumulating merit is the most secure way to acquire a kingdom, or whatever else one wishes to acquire in a future life. The Jātakas show that accumulating merit is also essential for reaching the highest aim there is, that of becoming a Buddha. Innumerable inscriptions confirm that the advice to accumulate merit was taken to heart by rulers and subjects, by monastics and lay people alike. 
If we now return to the Jătakas, it will be clear that these stories could become examples of ideal behavior for all those who wished to increase their stock of merit, including those who had not decided to become Buddhas themselves. These stories often emphasize the generous or compassionate aspect of this or that earlier incarnation of the Buddha. But they do more. They show that one can be a totally committed Buddhist, even a future Buddha, while yet continuing to occupy a role in society. Living in the world is compatible with being a Buddhist in the strictest sense of the term. But living in the world also means living in accordance with the norms of society. Depending on the position one occupies, one may even be obliged to kill. In this way, the question that must have occupied many Buddhists: "Can one be a Buddhist and live in society?" found its most poignant expression in the question "Can one be a Bodhisattva and kill?" This last question is discussed in a number of texts belonging to the movement that was particularly interested in the careers of Bodhisattvas, and which came to be known as the Bodhisattva-yāna or Mahā-yāna. ${ }^{50}$ Not surprisingly, this issue raises a number of questions, for example about the state of mind of the Bodhisattva and that of his victim while the former kills the latter. ${ }^{51}$

Related to the question of killing is that of whether war is ever justified. The Mahāyāna Mahāparinir vāṇa Sūtra states in so many words that lay Buddhists must protect Buddhist teaching, if necessary with the help of arms. It further states that killing certain people - those who reject Mahāyāna and adhere to particularly unwholesome views and practices-is less bad than killing animals; what is more, it constitutes no infringement of the prohibition to kill. ${ }^{52}$ Enemies of Buddhism, the Sarvadurgatipariśodhan a Tantra adds, should be killed where possible. ${ }^{53}$ The Bodhisattvabhūmi points out that a Bodhisattva who is king commits a serious transgression if he does not threaten severe punishment in order to impose virtuous behavior on his subjects, even against their will. ${ }^{54}$

Once Buddhism had resolved the issue of how one could be a layman in society and yet be counted as a devout Buddhist, its competition with Brahmanism took a different shape. Brahmanism had always had the great advantage of being able to counsel political rulers in a most practical fashion. It had been able to assure those rulers that the violence they sometimes had to commit was in keeping with their position in society and was indeed part of their duty. Now that the Buddhists had come to realize that the Buddha himself had been king in earlier existences ${ }^{55}$ and had competently ruled the kingdoms he had been in charge of, they could no longer blame present rulers for carrying out their task using the means required. This opened up new possibilities. 
They might henceforth aspire to the position of royal counselor in political matters, just as the Brahmins had done so far. ${ }^{56}$

A beautiful example of a Buddhist minister who justifies the kingship of his ruler in Buddhist terms comes from the kingdom of Ankor, in presentday Cambodia. ${ }^{57}$ The ruler concerned is Jayavarman V, who ruled from 968 to $1001 \mathrm{CE}$. From his realm a considerable number of inscriptions have been preserved, one of which, the so-called Vat-Sithor inscription, merits our attention. The Buddhist minister called Kīrtipaṇita figures prominently in this inscription, which contains some Buddhist propaganda. For our present purposes it is most interesting that both the king and his minister Kīrtipandita are characterized as Bodhisattvas whose deeds are guided by the unique concern to lead their subjects to heaven and liberation. What the king expects from his subjects, moreover, is in agreement with the true teaching (dharma, saddharma) of the Buddha, and conducts his subjects to better rebirths and liberation. Rulers could thus compare themselves to Bodhisattvas, or even to a Buddha. When the Pāla ruler Devapāla gained the throne, he repeatedly stated that he did so just as a Bodhisattva obtains the position of a Buddha, following the parinir vāna of the previous teacher of the world. ${ }^{58}$

Once it had become possible for Buddhists to act as counselors of the king, they could profit from the experience and expertise that the Brahmins had acquired in the course of time. More particularly, they might use the manuals that had been composed by Brahmins, among them the Arthasasstra and the Laws of Manu. Evidence illustrating this comes from Sri Lanka. The rulers of this island and their Buddhist counselors used these Brahmanical texts for running the country. ${ }^{59}$

There is no need to search for further examples. Whether or not the Buddhists succeeded in becoming political counselors at the royal courts, they could now legitimately aspire to such positions. They could do so because they had come to accept society as a legitimate place to live in, not just as something to flee from. This new development reduced the gap between Buddhists and Brahmins to a considerable extent. However, the Brahmins had one more trump card. They did not just offer political counseling. They also offered the magical protection, which only they, as possessors of traditional Vedic lore, could provide. It seems a fair bet that many rulers appreciated this magical protection as much as they did the political counseling, if not more so. In the realm of magical protection, traditional Buddhism had not much to offer. Neither the ascetic practices laid down in the ancient texts nor the rationalized doctrines, which Buddhists defended in their Sanskrit debates, provided magical protection in any form whatsoever. Certain Buddhists may have come to experience this as a 
drawback, one that might deprive them of the political support that they yet desperately needed.

It is no doubt in this context that we have to understand the ever-stronger tendency in Buddhism to use rites and spells. This tendency was not confined to Buddhism, to be sure, nor was it limited to rites and spells that might be of use to the royal court. ${ }^{60}$ It would not be correct either to say that there was once a time when Buddhism was completely without them. Protective spells are a common feature of Mahāyāna, and they appear to have been in use already in earlier phases of Buddhism. ${ }^{61}$ Philosophically inclined Buddhists held various views about the nature and value of mantras. ${ }^{62}$ Yet it seems clear that there was an upsurge of rites and spells from the seventh century CE onward. ${ }^{63}$ It is customary to speak in this connection of Tantric Buddhism. The available evidence suggests that Tantric Buddhism borrowed extensively from non-Buddhist religious currents, most notably Śaivism. ${ }^{64}$

In a recent article, Alexis Sanderson enumerates a number of factors that contributed to the success of the relevant form of Śaivism. One of these is "that the Śaivism of the Mantramārga developed in practice a thorough accommodation of the brahmanical religion that it claimed to transcend, thus minimizing, even eliminating, the offence it gave as a tradition whose scriptures, like those of the Buddhists, were seen to be, and claimed to be, outside the corpus of the Vedas. These Śaivas were to accept that the brahmanical tradition alone was valid in the domain it claimed for itself and that they were bound to follow its prescriptions and incorporate its rituals beside their own wherever practicable." ${ }^{65}$ This process sometimes worked in the opposite direction, as Sanderson points out in another article: in order to respond to the altered expectations of their royal clients, Brahmins of the Athar vaveda added "Śaiva and Vaisnava rituals to their repertoire, composing or appropriating texts that prescribe them and adding these to the corpus of their sacred literature. ${ }^{96}$ Evidence for this is provided by certain ancillary tracts included in the Athar va vedapariśista.

Another factor, the most vital according to Sanderson, "is that the religion succeeded in forging close links with the institution of kingship and thereby with the principal source of patronage. ${ }^{967}$ It did so in various ways. For instance, Śaiva officiants occupied the office of Royal Preceptor (rājaguru) and in this position gave Śaiva initiation (dīkșā) to the monarch followed by a specially modified version of the Śaiva consecration ritual (abhiseka) as an empowerment to rule beyond that conferred by the conventional Brahmanical royal consecration (rājyābhiseka). They provided a repertoire of protective, therapeutic, and aggressive rites for the benefit of the monarch and his kingdom. They developed Śaiva rituals and their applications to enable a specialized class of Śaiva officiants to encroach on the territory of the Rājapurohita, 
the Brahmanical expert in the rites of the Atharvaveda who served as the personal priest of the king, ${ }^{68}$ warding off all manner of ills from him through apotropaic rites, using sorcery to attack his enemies, fulfilling the manifold duties of regular and occasional worship on his behalf, and performing the funerary and other postmortuary rites when he or other members of the royal family died. ${ }^{69}$

The Śaivas were not, however, the only ones to attempt to forge links with royalty in this manner. Buddhists tried to imitate them in this respect, too. Sanderson gives some examples:

We see similar cases of regularization of rites of royal protection in our evidence for the Buddhist Way of Mantras. The Rgya gar chos 'byun, the Tibetan history of Indian Buddhism completed by Tāranātha in $\mathrm{AD} 1608$, reports that in order to protect his dynasty, expand its rule, and spread the Buddhist religion the Pāla king Dharmapāla (r. c. 775-812) had a fire-sacrifice performed regularly for many years by Tantric officiants under the direction of his Guru Buddhajñānapāda at an overall cost of 902,000 tolas of silver.

An inscription of the reign of Jayavarman V (r. c. 968 - c. 1000/1) reveals a similar arrangement in the Khmer court of Angkor. It tells us that one Kīrtipandita, a Mahāyānist scholar and adept of the Buddhist Yogatantras, who had been adopted by the royal family as their Guru, was frequently engaged by the king to perform apotropaic, restorative and aggressive Mantra rituals within the royal palace for the protection of his kingdom. ${ }^{70}$

We met the Kïrtipandita here mentioned earlier: this Buddhist minister was apparently appreciated at the Khmer court for his ability to perform even violent and aggressive Mantra rituals. ${ }^{71}$ There is not much direct evidence from South and Southeast Asia to show that the new emphasis on incantations and rites had as one of its aims to secure a place for Buddhists at the royal court, apart from the cases just considered. It is worth mentioning here the description of a war machine in an Indian Buddhist Tantric text, the Kālacakra Tantra. ${ }^{72}$ This description, unexpected in a Tantric text, may find a partial explanation in the fact that this text foresees a final and definitive battle between Buddhism and Islam in which the latter will be destroyed. It also shows the proximity that was felt to exist between Buddhism and the political powers that were to make use of this war machine.

Brahmanical literature is full of stories about ascetics with powers far exceeding those of any king. Tantric Buddhism, too, came to have its powerful ascetics, often called siddhas ("accomplished ones"). This topic cannot be explored here, but one story from Abhayadatta's Caturaśîtisiddhapravṛtti may be presented by way of illustration: 
In the city of Kansati, Virūpa bought wine from a tavern girl; she gave him a glass of wine and a plate of rice, which he greatly enjoyed. He continued eating and drinking. For the space of two days and a night, he prevented the sun from moving and the king, amazed, exclaimed: "Who is it who performs such a miracle?" In answer, the goddess of the sun appeared to the king in a dream and said, "A yogin has pledged me as payment to a tavern girl." The king and his subjects paid the price of the wine, which came to a million glasses, and Virūpa disappeared. ${ }^{73}$

Geoffrey Samuel, who cites this story, comments: "What is ... notable about this story is the implicit comparison of Virūpa's Tantric power and the king's temporal power." 74 Indeed - as is the case in many Brahmanical stories-it is clear that the king's power cannot compare with that of the ascetic. In other words, Tantric Buddhism, like Brahmanism before it, claimed great powers, which the king would be wise to respect and honor.

If the evidence from South Asia concerning the political role that Buddhist rites and spells were meant to play is limited, it is known that Buddhism owed much of its attraction in China, Japan, and elsewhere to its supposed capacity to defend the state against danger. It may be true, as Ronald Davidson points out, that "Indian esoteric Buddhism did not arise for the express purpose of converting the courts and appealing to the intelligentsia of Tibet, China, Japan, Burma, or elsewhere," but it is equally true that "its success was ... dramatic in these areas". ${ }^{75}$ The Tantric master Amoghavajra, to take an example, helped to defeat the invasion of China in 742 CE by a combined force of Tibetans, Arabs, Sogdians, and others. He did this through certain rituals derived from a Buddhist text specifically concerned with the protection of the state. ${ }^{76}$ Buddhist monks in China were exempted from military service, but were expected to execute Tantric Buddhist rites that would provide protection against natural and other disasters, most in particular against war and enemies. ${ }^{77}$ In Japan, in $940 \mathrm{CE}$, the state was threatened by a rebellion. The Shingon priest Kanjo was directed by the Emperor to bring an image of Fūdō, a Tantric deity, to Narita in order to defeat the rebellion. After three weeks of continual fire offerings, the leader of the rebellion, Taira no Masakado, was killed by the Emperor's forces and peace was restored. At least some of the credit was given to the Fūdō rituals. ${ }^{78}$ Geoffrey Samuel presents an interesting argument to show that one of the reasons why Tibet adopted Buddhism in the eighth century was identical with or similar to that which attracted the Chinese and the Japanese, that is, to secure the state and the position of the king. ${ }^{79}$ Also, later, rituals were used in Tibet to secure the subjugation or annihilation of enemies. ${ }^{80}$ It follows from these and other examples that there are plenty of reasons to think that the Tantric turn of Buddhism opened up a niche that had so far been inaccessible 
to this religion, and which the Buddhists had been accustomed to leave to the Brahmins.

There is another feature of Tantric Buddhism that might be taken as evidence for the political role that its rites and spells were meant to play. Tantric Buddhist ritual, as Ronald Davidson points out, is full of political metaphors. This imperial metaphor, as Davidson calls it, finds expression in the explicit relationship between the initiatory ritual of the abhiseka and the coronation ritual of kingship. ${ }^{81}$ The mandalas that serve as objects of meditation, moreover, "are implicitly and explicitly articulations of a political horizon in which the central Buddha acts as the Rājādhirāja [Supreme Overlord, JB] in relationship to the other figures of the mandala." Moreover, "Buddhists derived their mandala forms and functions ... from their immediate observation at the disposition and execution of realpolitik in their environment." These and other examples show that esoteric Buddhism internalized the political models of medieval India. Davidson suggests that, in this way, "the great litterateurs and teachers of North Indian monasteries [were] trying to sanctify the world as they received and accepted it." The mission of Buddhist cloisters, he adds, "was a consensual effort at sanctifying society." ${ }^{82}$ This, if true, is of course of the greatest interest in our present context. Buddhism had always abstained from justifying society in any of its forms, not to speak of sanctifying it. Davidson's analysis suggests that the Buddhist attitude to society had changed most radically.

Does this mean that Buddhism had now succeeded in freeing itself from the weight of Brahmanism? For many centuries, though not right from the beginning, subcontinental Buddhism had conceded to a form of cohabitation with Brahmanism in which the latter was responsible for matters of state, society, and much else. It took Buddhists many centuries to emancipate themselves from this tutelage. Had they finally succeeded now that they could admit that Buddhists, too, could play roles in society, including the role of ruler or counselor to the ruler? And that they could compete with Brahmins even in the domain of rites and incantations? To some extent, the answer is no doubt yes. Buddhists could now develop ideas about the way the state should be run, and they could now offer the kind of supernatural protection that had always been provided by Brahmins. ${ }^{83}$ However, the Buddhists remained indebted to Brahmanism in various ways. This can be seen as follows.

The Buddhists of South Asia had not developed any realistic ideas about statecraft of their own. They had slowly come to accept many of the Brahmanical ideas. They themselves never produced more than modified versions of these Brahmanical ideas. The Buddhist concept of the ruler as a Bodhisattva was new, to be sure, as was the accompanying view that rulers acted for the soteriological well-being of their subjects. In practical terms, however, I know of no evidence 
that might show that Buddhists in South and Southeast Asia really struck out on their own. The Brahmanical model was and remained the basis of their political thought.

In the realm of supernatural protection by means of rites and spells, one might expect a greater distance from the Brahmanical tradition. Buddhists underwent in this area the influence of Śaivism, which was itself in competition with traditional Brahmanism. In spite of this, Tantric Buddhism contains many features that were directly taken from the orthodox Brahmanical tradition. Shrikant Bahulkar has shown, in a private communication, that Vedic concepts, practices, and even a Rgvedic mantra found a place in this form of Buddhism. Its texts do not even hesitate to mention the Brahmanical division of society into four classes (varna), whose existence they clearly take for granted. As an example of this last feature we may consider three parallel Buddhists texts dealing with a rite called the Ahorātravrata. All three of these texts contain detailed stipulations as to the ways Brahmins, Kṣatriyas, Vaiśyas, Śūdras, and those belonging to lower castes should perform their worship. The lowest castes are discouraged from worshipping at all, or at the very least they are told to stay far away from the object of veneration. ${ }^{84}$

South Asian Buddhists, then, have had little opportunity to reassert themselves against the Brahmins who had been their rivals for so long. Their ultimately unsuccessful attempts at doing so took them far from the ideas and practices they had adhered to during the early centuries of their religion, and dangerously close to their much-detested rivals. Most notably, their competition with the Brahmins offered no opportunity to develop ideas about political peace. Quite on the contrary, where Indian Buddhism had originally looked with disapproval upon all forms of violence, including political violence, in the course of time they found ways to justify and contribute to it.

\section{Conclusion}

What does all this mean? In one sentence, it means that Indian antiquity has produced no credible ideas about political peace. This may look surprising in a civilization in which mental peace played such an important role. Mental peace is central in Buddhism and in many manifestations of Brahmanism. To be sure, there may be an element of rhetoric in this claimed interest in mental peace, but it seems undeniable that it represented a real concern to at least some Brahmins and Buddhists. Typically, the standard way to attain this mental peace was by leaving human society altogether. Human society, even in periods of political peace, was often rejected as not conducive to mental peace. This does 
not change the fact that many of those in search of mental peace would have benefited from a society in which there was political peace: they usually depended upon the gifts provided by members of society. However, thinkers did little to promote political peace. Those Brahmins whose influence was felt at the court were too occupied with promoting their own interests, and many of the others (primarily the Buddhists), having first left this responsibility to those Brahmins, ended up trying to imitate them. In this way they entered into competition with the Brahmins even in the realms that they had initially ceded to them. The result was that war was endemic in India for all but the few periods in which one kingdom succeeded in uniting a major part of the subcontinent under a single ruler. Thinking about political peace did not play a credible role in ancient India and never exerted a noticeable influence.

The Christian priest Charles Freer Andrews, a friend and admirer of Mahatma Gandhi, wrote to the latter in 1918, praising Indians who "as a race did repudiate bloodlust." Gandhi did not agree with his friend, and it will be interesting to cite his words:

Is this historically true? I see no sign of it either in the Mahabharata or the Ramayana, not even in my favourite Tulsidas... The incarnations [of God] are described as certainly bloodthirsty, revengeful and merciless to the enemy. They have been credited with having resorted to tricks also for the sake of overcoming the enemy. The battles are described with no less zest than now, and the warriors are equipped with weapons of destruction such as could be possibly conceived by the human imagination. The finest hymn composed by Tulsidas in praise of Rama gives the first place to his ability to strike down the enemy... The code of Manu prescribes no such renunciation that you impute to the race. Buddhism, conceived as a doctrine of universal forbearance, signally failed, and, if the legends are true, the great Shankaracharya did not hesitate to use unspeakable cruelty in banishing Buddhism out of India... Even among the Jains the doctrine has signally failed. They have a superstitious horror of blood(shed), but they have as little regard for the life of the enemy as a European. ${ }^{85}$

Gandhi had no illusions about the nonviolent nature of his own "race." Perhaps characteristically, it was a foreigner who attributed to India the tendency to nonviolent politics, and the modern apostle of nonviolence par excellence, Gandhi, who knew better.

\section{Notes}

1 Especially at the beginning of this chapter, there is some overlap with Richard Salomon's “Ancient India: Peace within and War without” (2007).

2 Thapar 1963: 255-56.

3 Ibid. 256.

4 Bakker 2006: 29. 
5 I believe that Cristina Scherrer-Schaub (2007: 762 n. 14) must be right in thinking that the memory of the "epigraphical" Aśoka survived him for many centuries. The fact that both Rudradāman (ca. $150 \mathrm{CE}$ ) and Samudragupta (two centuries later) left inscriptions in places where there were already inscriptions of Aśoka (Falk 2006: 118-19, 158-59) may be understood as supporting this belief. Far from being "curieux" and "peu digne d'un grand souverain" (Fussman 2007: 707 ), is it not possible that these rulers thus augmented their glory through association with the great former emperor? The "literary" Aśoka exerted an influence on more recent rulers, most notably Kanișka; see Deeg 2012.

6 Scharfe 1989: 51.

7 See Trautmann 1971: 10-68 for an analysis of the story of Cannakya and Candragupta in the various sources. Further McClish \& Olivelle 2012: xi ff.

8 For the most recent enumeration of arguments against this identification, see Olivelle 2013: 31-38.

9 Note that the Arthasanstra (2.10 and elsewhere) is familiar with writing and scribes (lekhaka).

10 Fussman 1987-1988: 46.

11 The surviving Arthaśāstra is, as a matter of fact, a composite text, dating from "the first or perhaps the second century A.D." (Scharfe 1993: 293), "100 вСE-100 CE" (McClish \& Olivelle 2012: xx-xxi). See further Trautmann 1971: 174ff.; Bronkhorst 1991; 2011: $\$ 2.3$.

12 McClish \& Olivelle 2012: 156.

13 Ibid. xlvii.

14 Ibid. 123.

15 Trans. Olivelle 2005.

16 Trans. Olivelle 1997; 2006.

17 See Fussman 1980: 387: "L'Inde ancienne ne connaît pas de distinction entre guerre juste et guerre injuste, entre guerre d'agression et guerre défensive. La guerre n'a pas à être justifiée. Elle est le devoir du kṣatriya —et sa raison d'être."

18 They are accessible in the many (42) volumes of the Epigraphia Indica and other such collections.

19 Gommans 1999: 305.

20 In his contacts with contemporary kings, the Buddha abstained from giving them political advice, if the early sources are to be trusted: Bareau 1993: 38 .

21 Meisig 1988: 142ff.

22 Trans. ibid. 413.

23 For the parallel in Chinese translation, see Warder 1980: 165-66.

24 Walshe 1987: 397-98.

25 Hartmann 1987: 36-37.

26 Thapar 2002: 221.

27 Hahn 1999: 38-39.

28 Mātrceța was the intellectual "grandchild" of Nāgārjuna according to Bu ston and Tārānātha, but the value of this testimony is dubious (Hartmann 1987: 36). Another Buddhist author belonging roughly to the same time is Āryadeva, who 
wrote critically about kings in the fourth chapter of his Catuhśataka; see Lang 1986: 46-47; 1992.

29 Hopkins 1998: 118.

30 Ibid. 148.

31 Jamspal et al. 1978: 14.

32 Ibid. 65.

33 Johnston (1936: II. xiv) provides a piece of evidence, which he does not press, suggesting that Mātrceta is somewhat later in date than Aśvaghoṣa.

34 Buddhac 9.40-41, 43.

35 Abhidh-k-bh(P) 4.36, p. 221 1. 13-15; Abhidh-k(VP) vol. 4 p. 91.

36 For the sometimes violent forms that this competition took, see Verardi 2011.

37 See the historical surveys by Pingree (1981) and Plofker $(2007,2009)$; further Bronkhorst 2007.

38 Lingat 1989: 152-53; Bronkhorst 2010.

39 The Jainas, here as elsewhere, adjusted more easily, as may be clear from the following (Flügel 2007: 3-4): "Jaina texts on kingship, statecraft and personal law were composed in contexts where individual Jain mendicants exercised personal influence over one or other 'Hindu' king or local official. The majority of the texts were created by monks of the Digambara tradition which had a sustained influence on the ruling dynasties in the Deccan between the eighth and twelfth centuries. The most significant Jaina works on statecraft are the Ādipurāṇa of Ācārya Jinasena (ca. 770-850 CE) and the Nîtivākyāmrtam (ca. 950 CE) and the Yaśastilaka (959 $\mathrm{CE}$ ) of Ācārya Somadeva Sūri. Both authors were associated with the rulers of the Rāṣtrakūta empire. The Ādipurāna belongs to the genre of universal history. It tells the life story of the first Jina, the legendary first king and law-giver rșabha, in the manner of a Jaina Mahābhārata, and for the first time offers blueprints for Jain social rituals and Jain kingship through the Jainization of Brāhmanical prototypes. The Nītivākyāmrtam, by contrast, is an entirely secular text on statecraft modelled on the Arthasāstra of Kautilya ... with barely noticeable emphasis on Jaina morality." This last text "barely shows any Jain traits at all." (Dundas 1991: 176).

40 La Vallée Poussin 1925; 1927: 47-48.

41 Wangchuk 2007.

42 Jātakas also inspired people who did not wish to become Buddhas themselves, perhaps already at a time when the Bodhisattva ideal did not yet exist; see Walters 1997: 166.

43 Bodhisattvas characterize primarily Mahāyāna (on which below), but not exclusively so; see Samuels 1997; Appleton 2010: 91-108.

44 Nattier 2003: 223, 225, 226.

45 Ibid. 246.

46 Shih 1994: 35.

47 It goes without saying that a Bodhisattva keeps his wealth in order to benefit others: "A bodhisattva is not covetous of his body, life, or wealth. If he protects his body, life, and wealth, it is to regulate sentient beings" (ibid. 54).

48 Ibid. 57. 
49 Ibid.

50 It may be useful to recall Skilling's (2005: 270-71) observation that Śrāvakayāna and Mahāyāna are "[t]wo of the most overworked categories in Buddhist studies:" "we have reified the categories and treated Śrāvakayāna and Mahāyāna as discrete historical agents and movements, when they are meant to describe related processes of intellectual interaction, often intense dialogue and debate, within a single (but infinitely variable) imagination, Buddhism. The categories are meant to provide a background, to help us sort out our data, but they have marched on to the stage and taken over the show."

51 See Schmithausen 2007; also 1996: 76-77; 1999: 59; further Kleine 2003: 246-47.

52 Schmithausen 1996: 75; 1999: 57-58. The Mahāyāna Angulimālīya Sūtra expresses itself similarly: Schmithausen 2003.

53 Schmithausen 1996: 76; 1999: 58; Skorupski 1983: 66, 218.

54 Schmithausen 2003: 42-43.

55 Many hundreds of times the Buddha had been a universal ruler (rājā cakkavattī), already according to the Anguttara Nikāya (AN IV p. 89).

56 Note that “the Rāja dhar ma -n yāya -sāastra, part of the massive Yogācārabhūmiśāstra ascribed to Maitreya and Asanga (early centuries CE), puts kingship into the larger scheme of a Bodhisattva's development as accepted by the Yogācāra school; it strongly emphasizes morality, though the urge for world conquest is not quite reconciled with non-violence" (Scharfe 1989: 22, with a reference to Jan 1984).

57 Mertens 2000.

58 Davidson 2002: 89.

59 Lingat 1989: 152; Bechert 1966: 24.

60 Some certainly were. Gray (2007: 252) gives an example from the Cakrasamvara Tantra of "a fierce homa rite for the purpose of subduing a rival kingdom."

61 See Snellgrove 1987: 121-22; Bongard-Levin et al. 1996: 30-31; Skilling 1997: 63-64; 2007; Davidson 2002: 144-45. The gān dhārī vidyā (Pāli gan dhārī nāma vijjā) "spell (?) from Gandhāra” (Tucci [1963: 147-48] proposes: “a magical formula connected with or placed under the control of Gāndhārī [the Devī from Gandhāra]") is already referred to in the Kevaddha Sutta of the Dīgha Nikāya (DN I p. 213). Early dhāraṇīs are found in the texts from Gilgit; see Hinüber 1981.

62 Braarvig 1997; Eltschinger 2001, 2008.

63 Davidson 2002: 116-17.

64 Sanderson 1988: 678-79; 1994; but see White 2005: 8-9.

65 Sanderson 2005: 231-32; see also Sanderson 2007b: 231-32.

66 Sanderson 2007a: 196.

67 Sanderson 2005: 232; see also Gupta and Gombrich 1986; Sanderson 2007b: $241-42,288-89$.

68 On the precise qualifications of Purohitas and their historical development, see Inden 1992.

69 Sanderson 2005: 233, 238-39.

70 Ibid. 238. 
71 Kīrtipandita was mentioned above at n. 57. On the expression of violence in Buddhist Tantric mantras, see Verhagen 1999.

72 Grönbold 1996.

73 Samuel 1993: 431, citing from Robinson 1979: 29.

74 Samuel, ibid.

75 Davidson 2005: 23-24.

76 Samuel 2002: 10, with a reference to Chandra 1992. For the activities of Tantric Buddhists at and around the imperial court, see Strickmann 1996: 213-14.

77 Demiéville 1957: 355; see also Shen 2004.

78 Samuel 2002: 11.

79 Samuel 2002.

80 Schmithausen 1996: 80-81. On the not altogether idyllic nature of traditional Tibetan society, see Parenti 2007; Trimondi and Trimondi 1999: 478-79. Western notions of Tibet are exposed in Lopez 1998.

81 Davidson 2002: 123-24.

82 Quotes: ibid. 131, 139, 160, 161.

83 One would think that they might even occupy themselves with astrology and related sciences. It is in this connection interesting to note that Amoghavajra, the Tantric Buddhist master in China whom we met before (at n. 76 above), is also reported to have been the author of a text on Indian astrology (Yano 1987).

84 Handurukande 2000: xvii, 22-23, 75-76, 88, 107-8, 120, 125.

85 Letter of July 6, 1918: Gandhi 1965: 474-75.

\section{Abbreviations}

Abhidh-k-bh(P) Vasubandhu, Abhidharmakośabhāṣya. Ed. P. Pradhan. $2^{\text {nd }}$ rev. ed. by Aruna Haldar. Patna 1975.

Abhidh-k(VP) Vasubandhu, Abhidharmakośa, traduit et annoté par Louis de La Vallée Poussin. 6 vols. Paris 1923-1931.

AN Añguttara-Nikāya. Ed. R. Morris and E. Hardy. 5 vols. London 1885-1900; vol. 6 (Indexes, by M. Hunt and C.A.F. Rhys Davids). London 1910.

Buddhac Aśvaghoṣa, Buddhacarita. Ed. and trans. E.H. Johnston. Calcutta 1935. DN Dīghanikāya. Eds. T.W. Rhys Davids and J.E. Carpenter. 3 vols. Patna 1890-1911.

\section{References}

Aggañña Sutta. See Walshe 1987: 407-15; also Collins 1993.

Appleton, N. 2010. Jātaka Stories in Theravāda Buddhism: Narrating the Bodhisatta Path. Farnham.

Arthaśāstra. See Kangle 1969; Olivelle 2013. 
Bakker, H. 2006. “The Hindu religion and war.” In King, A. S. (ed.), Indian Religion s: Renaissance and Renewal, 28-40. London.

Bareau, A. 1993. "Le bouddha et les rois." Bulletin de l'École française d'ExtrêmeOrient 80.1: 15-39.

Bechert, H. 1966. Buddhismus, Staat und Gesellschaft in den Ländern des TheravādaBuddhismus, I: Allgemeines und Ceylon. Frankfurt/Main.

Bongard-Levin, G., Boucher, D., Fukita, T., and Wille, K. 1996. “The Nagaropamasūtra: an apotropaic text from the Samyuktāgama. A transliteration, reconstruction, and translation of the central Asian sanskrit manuscripts." In F. Fumio Enomoto, J.-U. Hartmann, and H. Matsumura (eds.), Sanskrit-Texte au s dem buddhistischen Kanon: Neuentdeckungen und Neueditionen, III: 7-131. Göttingen.

Braarvig, J. 1997. "Bhavya on mantras: apologetic endeavours on behalf of the Mahāyāna.” Studia Indologiczne 4: 31-39.

Bronkhorst, J. 1991. "Two literary conventions of classical India." Asiatische Stu dien / Études Asiatiques 45.2: 210-27.

Bronkhorst, J. 2007. "Science and religion in classical India." Indologica Taurinensia 33: 183-96.

Bronkhorst, J. 2010. “The spread of Sanskrit.” In E. Franco and M. Zin (eds.), From Turfan to Ajanta. Festschrift for Dieter Schlingloff on the Occasion of his Eightieth Birthday, I: 117-39. Bhairahawa, Rupandehi.

Bronkhorst, J. 2011. Buddhism in the Shadow of Brahmanism. Leiden.

Cakkavatti-Sīhanāda Sutta. See Walshe 1987: 395-405.

Chandra, L. 1992. "Tantras and the defence of T'ang China." In Chandra, Cultural Horizon s of India, II: 257-66. New Delhi.

Collins, S. 1993. "The discourse on what is primary (Aggañña-Sutta): an annotated translation." Journal of Indian Philosophy 21.4: 301-93.

Davidson, R. M. 2002. Indian Esoteric Buddhism. A Social History of the Tantric Movement. New York.

Davidson, R. M. 2005. Tibetan Renaissance. Tantric Buddhism in the Rebirth of Tibetan Culture. New York.

Deeg, M. 2012. “Aśoka, model ruler without a name?” In P. Olivelle, J. Leoshko, and H. Prabha Ray (eds.), Reimagining Aśoka: Memory and History, 362-79. New Delhi and Oxford.

Demiéville, P. 1957. Le bouddhisme et la guerre. In Renondeau and Demiéville 1957: 347-85.

Dundas, P. 1991. "The Digambara Jain warrior." In M. Carrithers and C. Humphrey (eds.), The Assembly of Listeners: Jains in Society, 169-86. Cambridge.

Eltschinger, V. 2001. Dharmakīrti sur les mantra et la perception du supra-sensible. Vienna.

Eltschinger, V. 2008. "Dharmakīrti on mantras and their efficiency." In Esoteric Buddhist Studies: Identity in Diversity, 273-89. Koya-mati.

Falk, H. 2006. Aśokan Sites and Artefacts. A Source-book with Bibliography. Mainz.

Flügel, P. 2007. “A short history of Jaina law.” International Journal of Jaina Studies 3.4: 1-15. 
Fussman, G. 1980. “Le concept d'empire dans l'Inde ancienne.” In M. Duverger (ed.), Le concept d'empire, 379-96. Paris.

Fussman, G. 1987-1988. "Central and provincial administration in ancient India: the problem of the Mauryan empire." Indian Historical Review 14: 43-72.

Fussman, G. 2007. "Les Guptas et le nationalisme indien." Cours et travaux du Collège de France, Résumés 2006-2007: 695-711.

Gandhi, M. 1965. The Collected Works, XIV: October 1917 - July 1918. Delhi.

Gommans, J. 1999. "The embarrassment of political violence in Europe and South Asia c. 1100-1800." In Houben and van Kooij 1999: 287-315.

Gray, D. B. 2007. “Compassionate violence? On the ethical implications of tantric buddhist ritual." Journal of Buddhist Ethics 14: 239-71.

Grönbold, G. 1996. "Kriegsmaschinen in einem buddhistischen Tantra.” In F. Wilhelm (ed.), Festschrift Dieter Schlingloff zur Vollendung des65. Leben sjahres, 63-97. Reinbek.

Gupta, S.and Gombrich, R. 1986. "Kings, power and the goddess." South A sia R esearch 6.2: $123-38$.

Hahn, M. (trans.). 1999. Invitation to Enlighten ment: Letter to the Great King Kaniska by Mātṛceța \& Letter to a Disciple by Candragomin. Berkeley.

Handurukande, R. 2000. Three Sanskrit Texts on Caitya Worship in Relation to the Ahorātravrata. An edition and synopses in English. Tokyo.

Hartmann, J.-U. (ed., trans.). 1987. Das Varṇārha varṇa stotra des Mātṛceṭa . Göttingen.

Hinüber, O. von. 1981. "Namen in Schutzzaubern aus Gilgit." Studien zur Indologie und Iranistik 7: 163-71.

Hopkins, J. (ed., trans.). 1998. Buddhist Advice for Living \& Liberation: Nāgārjuna's Precious Garland. Ithaca NY.

Houben, J. E. M., and Kooij, K. R. (eds.). 1999. Violence Denied: Violence, NonViolence and the Rationalization of Violence in South Asian Cultural History. Leiden.

Inden, R. 1992. "Changes in the Vedic Priesthood." In A. W. van den Hoek, D. H. A. Kolff, and M. S. Oort (eds.), Ritual, State and Histor yin Sou th Asia: Essa ys in Honour of J. C. Heesterman, 556-77. Leiden.

Jamspal, L., Chophel, N. S. and della Santina, P. 1978. Nāgārjuna's Letter to King Gautamiputra. Delhi.

Jan, Y.-H. 1984. "Rājadharma ideal in Yogācāra Buddhism.” In P. Jash (ed.), Religion and Society in Ancient India: Sudhakar Chattopadhyaya Commemoration Volume, 221-34. Calcutta.

Johnston, E. H. (ed., trans.). 1936. The Buddhacarita or Acts of the Buddha. 2 parts. Lahore. Reprint Delhi, 1984.

Kangle, R. P. 1965, 1969, 1972. The Kauțilīya Arthasāastra. 3 parts. Bombay. Reprint Delhi, 1986-1988.

Kautilya: Arthaśāstra. See Kangle 1965-1972.

Kleine, C. 2003. "Üble Mönche oder wohltätige Bodhisattvas?” Zeitschrift für Religionswissen schaft 11: 235-58.

Lang, K. (ed., trans.). 1986. Ār ya deva 's Catuhśataka: On the Bodhisattva's Cultivation of Merit and Knowledge. Copenhagen. 
Lang, K. 1992. "Āryadeva and Candrakīrti on the dharma of kings.” Asiatische Studien / Étu des Asiatiques 46.1: 232-43.

La Vallée Poussin, L. de. 1925. "Notes bouddhiques, VI \$3: Les fidèles laïcs ou upāsakas." Bulletins de la cla sse des lettres et des sciences morales et politiques, Aca démie Royale de Belgique, $5^{\text {th }}$ ser. 11: 15-34.

La Vallée Poussin, L. de. 1927. La morale bouddhique. Paris. Repr. Paris, 2001.

Lingat, R. 1989. Royautés bouddhiques. Aśoka et La fonction royale à Ceylan. Eds. G. Fussman and É. Meyer. Paris.

Lopez, D. S. 1998. Prisoners of Shangri-La. Tibetan Buddhism and the West. Chicago. Manu: Laws of Manu. See Olivelle 2005.

McClish, M. and Olivelle, P. 2012. The Arthaśāstra: Selection s from the Cla ssic Indian Work on Statecraft. Indianapolis.

Meisig, K. 1988. Das Sūtra von den vier Ständen. Das Aggañ̃̃a-Sutta im Licht seiner chinesischen Parallelen. Wiesbaden.

Mertens, A. 2000. "Beobachtungen zur Herrschaftslegimitation im Ankkor-Reich: die buddhistisch orientierte Vat-Sithor-Inschrift von Jayavarman V." In C. Chojnacki, J.-U. Hartmann, and V. M. Tschannerl (eds.), Vividharatnakarandaka. Festschrift für Adelheid Mette, 395-411. Swisttal-Odendorf.

Nāgārjuna: Letter to King Gautamīputra. See Jamspal et al. 1978.

Nāgārjuna: Ratnāvalī/ Preciou s Garland. See Hopkins 1998.

Nattier, J. 2003. A Few Good Men: The Bodhisattva Path according to the Inquiry of Ugra (Ugrapariprcchā). A Study and Translation. Honolulu.

Olivelle, P. 1997. Pañcatantra. The Book of In dia'sFolk Wisdom. New York and Oxford.

Olivelle, P. 2005. Manu's Code of Law: A Critical Edition and Translation of the Māna va -Dharmaśāstra. New York and Oxford.

Olivelle, P. 2006. The Five Discour ses on Worldly Wisdom by Viṣuuśarman. New York.

Olivelle, P. 2013. King, Governance, and Law in Ancient India: Kauțilya's Ar thaśāstra. A New Annotated Translation. New York and Oxford.

Parenti, M. 2007. "Friendly feudalism: the Tibet myth." www.michaelparenti.org/ Tibet.html\#notes (accessed November 20, 2015).

Pingree, D. 1981. Jyotihśāsstra: Astral and Mathematical Literature. Wiesbaden.

Plofker, K. 2007. "Mathematics in India." In V. Katz (ed.), The Mathematics of Egypt, Mesopotamia, China, India, and Islam: A Sourcebook, 385-514. Princeton.

Plofker, K. 2009. Mathematics in India. Princeton.

Renondeau, G., and Demiéville, P. 1957. Histoire des moines guerriers du Japon, by G. Renondeau; Le bou ddhisme et la guerre, by Paul Demiéville. Paris.

Robinson, J. B. (trans.). 1979. Buddha's Lions: The Lives of the EightyFour Siddhas. Caturaśîti-siddha-pravrtti by Abhayadatta. Berkeley.

Salomon, R. 2007. “Ancient India: peace within and war without.” In K. A. Raaflaub (ed.), War and Peace in the Ancient World, 53-65. Malden and Oxford.

Samuel, G. 1993. Civilized Shamans: Buddhism in Tibetan Society. Washington DC.

Samuel, G. 2002. "Buddhism and the state in eighth-century Tibet." In H. Blazer (ed.), Religion and Secular Culture in Tibet 1-19. Leiden. 
Samuels, J. 1997. "The Bodhisattva ideal in Theravāda Buddhist theory and practice: a reevaluation of the bodhisattva-śrāvaka opposition." Philosophy East and West 47.3: $399-415$.

Sanderson, A. 1988. "Śaivism and the tantric traditions." In S. Sutherland, L. Houlden, P. Clarke, and F. Hardy (eds.), The World's Religions, 660-704. London.

Sanderson, A.1994. "Vajrayāna: origin and function." In Buddhism into the Year 2000, 87-102. Bangkok and Los Angeles.

Sanderson, A. 2005. "Religion and the state: Saiva officiants in the territory of the king's brahmanical chaplain.” Indo-Iranian Journal 47 (2004): 229-300.

Sanderson, A. 2007a. "Atharvavedins in tantric territory. The Āngirasakalpa texts of the Oriya Paippalādins and their connection with the Trika and the Kālīkula. With critical editions of the Parājapavidhi, the Parāmantravidhi, and the Bhadrakālīmantravidhipr akarana." In A. Griffiths and A. Schmiedchen (eds.), The Atharvaveda and its Paippalādaśākhā: Historical and Philological Papers on a Vedic Tradition, 195-311. Aachen.

Sanderson, A. 2007b. "The Śaiva exegesis of Kashmir.” In D. Goodall and A. Padoux (eds.), Mélanges tantriques à la mémoire d'Hélène Brunner / Tantric Studies in Memor y of Hélène Brunner, 231-442. Pondichéry, Paris.

Scharfe, H. 1989. The State in Indian Tradition. Leiden.

Scharfe, H. 1993. Investigations in Kauțalya's Manual of Political Science. $2^{\text {nd }}$ rev. ed. of Untersuchungen zur Staatsrechtslehre des Kauțalya. Wiesbaden.

Scherrer-Schaub, C. 2007. "Immortality extolled with reason: philosophy and politics in Nāgārjuna.” In B. Kellner, H. Krasser, H. Lasic, et al. (eds.), Pramāṇakīrtị̣: Papers Dedicated to Ernst Steinkellner, part 2: 757-93. Vienna.

Schmithausen, L. 1996. "Buddhismus und Glaubenskriege." In P. Hermann (ed.), Glauben skriege in Vergangenheit und Gegenwart, 63-92. Göttingen.

Schmithausen, L. 1999. "Aspects of the Buddhist attitude towards war." In Houben and van Kooij 1999: 45-67.

Schmithausen, L. 2003. "Einige besondere Aspekte der 'Bodhisattva-Ethik' in Indien und ihre Hintergründe." Hōrin 10: 21-46.

Schmithausen, L. 2007. "Zur Frage, ob ein Bodhisattva unter bestimmten Voraussetzungen in einer neutralen Geisteshaltung (a vyākṛta-citta) töten darf." In K. Klaus and J.-U. Hartmann (eds.), Indica et Tibetica. Festschrift für Michael Hahn, 423-40. Vienna.

Shen, W. 2004. "Magic power, sorcery and evil spirit: the image of Tibetan monks in Chinese literature during the Yuan dynasty." In C. Cüppers (ed.), The Relation ship Between Religion and State (chos srid zung "brel) in Traditional Tibet, 189-227. Lumbini.

Shih, H.-C. 1994. The Sutra on Upāsaka Precepts. Translated from the Chinese of Dharmaraksa. Berkeley.

Skilling, P. 1997. Mahāsūtras: Great Discourses of the Buddha, II. 2 Parts. Oxford.

Skilling, P. 2005. "Cutting across categories: the ideology of relics in Buddhism." Annual Report of the International Research Institute for Advanced Buddhology at Soka University for the Aca demic Year 2004: 269-310. Tokyo. 
Skilling, P. 2007. "Zombies and half-zombies: Mahāsūtras and other protective measures.” Journal of the Pali Text Society 29: 313-30.

Skorupski, T. (ed., trans.). 1983. The Sar vadurgatipariśodhana Tantra: Elimination of All Evil Destinies. Delhi.

Snellgrove, D. L. 1987. Indo-Tibetan Buddhism: Indian Buddhists and their Tibetan Successors. London.

Strickmann, M. 1996. Mantraset mandarins. Le Bouddhisme tantrique en Chine. Paris. Thapar, R. 1963. Aśoka and the Decline of the Mauryas. Delhi and Oxford.

Thapar, R. 2002. The Pengu in History of Early India, from the Origins to AD 1300. London.

Trautmann, T. R. 1971. Kauțilya and the Arthaśāstra: A Statistical Investigation of the Author ship and Evolution of the Text. Leiden.

Trimondi, V. and Trimondi, V. 1999. Der Schatten des Dalai Lama. Sexualität, Magie und Politik im tibetischen Buddhismus. Düsseldorf.

Tucci, G. 1963. "Oriental notes II: an image of a devi discovered in swat and some connected problems." East and West 14: 146-82.

Verardi, G. 2011. Hardships and Downfall of Buddhism in India. Singapore and Manohar.

Verhagen, P. C. 1999. "Expressions of violence in Buddhist tantric mantras." In Houben and van Kooij 1999: 275-85.

Walshe, M. 1987. The Long Discourses of the Buddha: A Translation of the Dīgha Nikāya . Boston.

Walters, J. S. 1997. "Stūpa, story and empire: constructions of the Buddha biography in early post-Aśokan India.” In J. Schober (ed.), Sacred Biography in the Buddhist Traditions of South and Southeast Asia, 160-92. Honolulu.

Wangchuk, D. 2007. The Resolve to Become a Buddha. A Study of the Bodhicitta Concept in Indo-Tibetan Buddhism. Tokyo.

Warder, A. K. 1980. Indian Buddhism. $2^{\text {nd }}$ rev. ed. Delhi.

White, D. G. 2005. Review of Davidson 2002. Journal of the International Association of Tibetan Studies 1: 1-11.

Yano, M. 1987. "The Hsiu-yao Ching and its sanskrit sources.” In G. Swarup, A. K. Bag, and K. S. Shukla (eds.), History of Oriental Astronomy, 125-34. Cambridge. 